\title{
MYCOPLASMA INFECTION IN PREGNANT RATS: LOW VIABILITY OF FOETUSES AND NEWBORN OFFSPRING
}

\author{
Y. NAOT*, M. Sharf $\dagger$ AND A. KLEIN $\dagger$ \\ * Department of Immunology, Technion, School of Medicine, POB 9649, Haifa, Israel, and \\ $\dagger$ Department of Obstetrics and Gynaecology, Rothschild Hospital, Haifa, Israel
}

THE role of mycoplasmas in human reproductive failure is still controversial. This is because the risks associated with the infection of human volunteers make it necessary to rely on statistical comparisons of the incidence of mycoplasma infection in infertile couples with that in normal fertile couples. It is true that Mycoplasma hominis and T-strain mycoplasmas have been isolated from gestational products in instances in which birth was premature or newborn offspring were of low weight (Harwick et al., 1967; Jones, 1967a and $b$; Klein, Buckland and Finland, 1969; Kundsin and Driscoll, 1970; Braun et al., 1971; Caspi, Solomon and Sompolinsky, 1972). On the other hand, De Louvois et al. (1974) found no statistical difference between the rates of mycoplasma infection in fertile and infertile couples.

In view of this controversy, an animal model was examined by TaylorRobinson et al. (1975) who found that foetal wastage occurred as a direct consequence of Mycoplasma pulmonis infection in the mouse. Mice infected with $M$. pulmonis 9 days after mating showed an increase in foetal mortality.

In the present study, we have attempted to throw further light on the effects of mycoplasma infection both during gestation and in the neonatal period, and we discuss briefly a possible mechanism for mycoplasma pathogenicity.

The organism chosen for our study was Mycoplasma arthritidis, a murine mycoplasma that produces latent infections and becomes pathogenic under appropriate conditions of stress (Tully, 1969); it has been reported to induce polyarthritis, conjunctivitis and urethritis in experimentally infected mice and rats (Ward and Jones, 1962; Cole, Golightly-Rowland and Ward, 1976). It has been shown to be indistinguishable in serological, biochemical and pathological properties from a common organism, originally recovered from the human genital tract and classified as M. hominis type 2 (Lemcke, 1964; Tully, 1965; Cole et al., 1976). Further studies have shown that $M$. arthritidis strains can also be isolated from human tissues, thus supporting the concept that they may be either commensal or pathogenic in man. This influenced our choice of organism.

\section{MATERIALS AND METHODS}

Animals. Male and female Charles River rats aged 2 months were used. These animals were bred and reared under specific pathogen-free conditions.

Mycoplasma strain. M. arthritidis strain PG-6 was kindly provided by Dr J. G. Tully (NIAID-NIH, Bethesda, Maryland, USA). Broth and agar media were prepared by a

Received 27 July 1977; revised version accepted 1 Dec. 1977.

J. MED. MICROBIOL._-VOL. 11 (1978) 
TABLE I

Comparison of the first (normal) pregnancy of control rats with the following pregnancy during which they were inoculated with sterile broth medium

\begin{tabular}{|c|c|c|c|c|c|c|c|c|c|c|}
\hline \multirow[b]{2}{*}{$\begin{array}{l}\text { Animal } \\
\text { number }\end{array}$} & \multicolumn{5}{|c|}{ Observations on first pregnancy } & \multicolumn{5}{|c|}{ Observations on second pregnancy } \\
\hline & $\begin{array}{c}\text { Duration } \\
\text { of } \\
\text { pregnancy } \\
\text { (days) }\end{array}$ & $\begin{array}{c}\text { Weight } \\
\text { increase } \\
(\%) \text { of } \\
\text { dam* }\end{array}$ & $\begin{array}{c}\text { Total } \\
\text { number } \\
\text { of } \\
\text { offspring }\end{array}$ & $\begin{array}{c}\text { Number } \\
\text { of } \\
\text { offspring } \\
\text { alive at } \\
\text { birth }\end{array}$ & $\begin{array}{l}\text { Number } \\
\text { of } \\
\text { offspring } \\
\text { alive } 10 \\
\text { days after } \\
\text { birth }\end{array}$ & $\begin{array}{c}\text { Duration } \\
\text { of } \\
\text { pregnancy } \\
\text { (days) }\end{array}$ & $\begin{array}{c}\text { Weight } \\
\text { increase } \\
(\%) \text { of } \\
\text { dam }\end{array}$ & $\begin{array}{c}\text { Total } \\
\text { number } \\
\text { of } \\
\text { offspring }\end{array}$ & $\begin{array}{l}\text { Number } \\
\text { of } \\
\text { offspring } \\
\text { alive at } \\
\text { birth }\end{array}$ & $\begin{array}{c}\text { Number } \\
\text { of } \\
\text { offspring } \\
\text { alive } 10 \\
\text { days after } \\
\text { birth }\end{array}$ \\
\hline $\begin{array}{r}1 \\
2 \\
3 \\
4 \\
5 \\
6 \\
7 \\
8 \\
9 \\
10 \\
11\end{array}$ & $\begin{array}{l}23 \\
22 \\
22 \\
21 \\
22 \\
21 \\
22 \\
22 \\
22 \\
23 \\
22\end{array}$ & $\begin{array}{l}151 \\
164 \\
153 \\
147 \\
150 \\
151 \\
144 \\
141 \\
149 \\
151 \\
164\end{array}$ & $\begin{array}{r}5 \\
10 \\
13 \\
10 \\
11 \\
12 \\
10 \\
9 \\
10 \\
5 \\
10\end{array}$ & $\begin{array}{r}5 \\
10 \\
13 \\
10 \\
11 \\
12 \\
10 \\
9 \\
10 \\
5 \\
10\end{array}$ & $\begin{array}{r}5 \\
10 \\
13 \\
10 \\
11 \\
12 \\
10 \\
9 \\
9 \\
4 \\
10\end{array}$ & $\begin{array}{l}21 \\
22 \\
21 \\
21 \\
21 \\
21 \\
22 \\
22 \\
22 \\
21 \\
22\end{array}$ & $\begin{array}{l}149 \\
159 \\
134 \\
127 \\
141 \\
141 \\
145 \\
143 \\
147 \\
142 \\
148\end{array}$ & $\begin{array}{r}6 \\
13 \\
15 \\
11 \\
12 \\
12 \\
10 \\
8 \\
10 \\
6 \\
13\end{array}$ & $\begin{array}{r}6 \\
12 \\
15 \\
10 \\
12 \\
12 \\
10 \\
8 \\
10 \\
6 \\
13\end{array}$ & $\begin{array}{r}5 \\
12 \\
15 \\
9 \\
12 \\
12 \\
10 \\
8 \\
9 \\
5 \\
12\end{array}$ \\
\hline Total & 242 & 1665 & 105 & 105 & 103 & 236 & 1576 & 116 & 114 & 109 \\
\hline Mean & 22 & $151 \cdot 4$ & $9 \cdot 5$ & $9 \cdot 5$ & $9 \cdot 4$ & $21 \cdot 4$ & $143 \cdot 2$ & $10 \cdot 5$ & $10 \cdot 3$ & $9 \cdot 9$ \\
\hline
\end{tabular}

* Weight on 21st day of pregnancy expressed as a percentage of weight at the time of mating. 
modification of Hayflick's method (1965) as described on an earlier occasion (Beck, Ginsburg and Naot, 1977). Cultures were incubated at $37^{\circ} \mathrm{C}$ for 3-4 days and the suspensions stored at $-75^{\circ} \mathrm{C} ; 0 \cdot 1-\mathrm{ml}$ samples of serial tenfold dilutions were plated on agar and counted after incubation for 7 days. The numbers of organisms were expressed as colony forming units (CFU) per ml.

Experimental procedure. The phases of oestrus of each female animal were observed over two reproductive cycles, vaginal smears being taken by means of a glass spatula sterilised with $70 \%$ ethyl alcohol and immersed in sterile normal saline. Then, on the appearance of cornified cells in a smear, each female was placed in a cage with a male and left for about $20 \mathrm{~h}$. The presence of spermatozoa in a vaginal plug and their appearance in a vaginal smear were taken to indicate the onset of gestation. The presence of a plug without spermatozoa was considered inconclusive.

Advantage was taken of the first mating to eliminate infertile animals. Of a group of 45 females born on the same day five failed to conceive and were discarded. The remaining 40 were divided into two groups of 25 and 15. During their second pregnancy 7-11 days after conception, rats in the first group were inoculated intravenously with $1 \mathrm{ml}$ of mycoplasma suspension containing $10^{10} \mathrm{CFU}$; rats in the second group were kept in a separate room and served as controls, being inoculated with $1 \mathrm{ml}$ of sterile broth. Injections were administered under general anaesthesia with chloroform, maintained for about 2-3 min.

During the gestation period the animals were weighed daily or on alternate days, and examined for swollen joints daily, in order to estimate the progress of pregnancy and to detect arthritis. On the 20th day four or five animals in each group were killed and their ovaries, spleen, uterus and lungs, as well as foetuses and placentae (removed by caesarean section) were examined for mycoplasmas as described by Ganaway et al. (1973).

Sterile gloves were used when the litters were counted, and great care was taken to cause only a minimum of disturbance and so forestall devouring of the offspring. Offspring were examined for viability immediately after birth and subsequently every few hours for 10 days. Suckling was allowed for 21 days before the offspring were removed and the mothers rested for 14 days.

\section{RESULTS}

Tables I and II list the observations for the control group (11 rats) and experimental group (20 rats) respectively, and draw a comparison between the first (normal) and second (manipulated) pregnancies. Table III, derived from the data in tables I and II, summarises information on the effects of the mycoplasma infection.

\section{Experimental and control rats in their first (normal) pregnancy}

No significant differences occurred between the two groups in terms of mean gestation period, mean litter size, percentage of offspring alive at birth, and percentage of offspring alive 10 days after birth.

\section{Control rats in their first (normal) and second (manipulated) pregnancies}

No significant differences occurred between the two pregnancies in terms of mean gestation period, mean litter size, percentage of offspring alive at birth, and percentage of offspring alive 10 days after birth. In other words, inoculation of rats with broth 7-11 days after conception did not affect reproduction. However, in this study, as in a previous study (Klein et al., 1978), the inoculation of rats with broth 7-11 days after conception influenced to some extent the 
TABLE 11

Comparison of the first (normal) pregnancy of experimental rats with the following pregnancy, during which they were inoculated with mycoplasmas

\begin{tabular}{|c|c|c|c|c|c|c|c|c|c|c|}
\hline \multirow[b]{2}{*}{$\begin{array}{l}\text { Animal } \\
\text { number }\end{array}$} & \multicolumn{5}{|c|}{ Observations on first pregnancy } & \multicolumn{5}{|c|}{ Observations on second pregnancy } \\
\hline & $\begin{array}{c}\text { Duration } \\
\text { of } \\
\text { pregnancy } \\
\text { (days) }\end{array}$ & $\begin{array}{c}\text { Weight } \\
\text { increase } \\
(\%) \text { of } \\
\text { dam* }\end{array}$ & $\begin{array}{c}\text { Total } \\
\text { number } \\
\text { of } \\
\text { offspring }\end{array}$ & $\begin{array}{l}\text { Number } \\
\text { of } \\
\text { offspring } \\
\text { alive } \\
\text { at birth }\end{array}$ & $\begin{array}{c}\text { Number } \\
\text { of } \\
\text { offspring } \\
\text { alive } 10 \\
\text { days after } \\
\text { birth }\end{array}$ & $\begin{array}{c}\text { Duration } \\
\text { of } \\
\text { pregnancy } \\
\text { (days) }\end{array}$ & $\begin{array}{c}\text { Weight } \\
\text { increase } \\
(\%) \text { of } \\
\text { dam* }\end{array}$ & $\begin{array}{c}\text { Total } \\
\text { number } \\
\text { of } \\
\text { offspring }\end{array}$ & $\begin{array}{l}\text { Number } \\
\text { of } \\
\text { offspring } \\
\text { alive } \\
\text { at birth }\end{array}$ & $\begin{array}{c}\text { Number } \\
\text { of } \\
\text { offspring } \\
\text { alive } 10 \\
\text { days after } \\
\text { birth }\end{array}$ \\
\hline $\begin{array}{l}12 \\
13 \\
14 \\
15 \\
16 \\
17 \\
18 \\
19 \\
20 \\
21 \\
22 \\
23 \\
24 \\
25 \\
26 \\
27 \\
28 \\
29 \\
30 \\
31\end{array}$ & $\begin{array}{l}22 \\
22 \\
23 \\
21 \\
22 \\
22 \\
22 \\
23 \\
23 \\
22 \\
22 \\
22 \\
22 \\
22 \\
22 \\
22 \\
22 \\
21 \\
22 \\
22\end{array}$ & $\begin{array}{l}160 \\
154 \\
161 \\
149 \\
160 \\
165 \\
164 \\
159 \\
163 \\
152 \\
159 \\
171 \\
160 \\
149 \\
\text { ND } \\
152 \\
153 \\
166 \\
154 \\
153\end{array}$ & $\begin{array}{r}12 \\
10 \\
8 \\
10 \\
13 \\
10 \\
13 \\
10 \\
13 \\
11 \\
15 \\
17 \\
10 \\
9 \\
11 \\
10 \\
7 \\
12 \\
10 \\
11\end{array}$ & $\begin{array}{r}12 \\
10 \\
8 \\
10 \\
13 \\
10 \\
13 \\
10 \\
13 \\
11 \\
15 \\
17 \\
10 \\
9 \\
11 \\
10 \\
7 \\
11 \\
10 \\
11\end{array}$ & $\begin{array}{r}12 \\
10 \\
8 \\
10 \\
13 \\
10 \\
12 \\
10 \\
13 \\
11 \\
15 \\
16 \\
10 \\
9 \\
10 \\
10 \\
7 \\
11 \\
10 \\
11\end{array}$ & $\begin{array}{l}21 \\
22 \\
22 \\
22 \\
21 \\
22 \\
22 \\
22 \\
22 \\
22 \\
21 \\
21 \\
21 \\
22 \\
21 \\
20 \\
22 \\
22 \\
22 \\
22\end{array}$ & $\begin{array}{l}129 \\
128 \\
126 \\
149 \\
127 \\
148 \\
127 \\
121 \\
132 \\
140 \\
134 \\
123 \\
137 \\
125 \\
\text { ND } \\
120 \\
164 \\
136 \\
144 \\
140\end{array}$ & $\begin{array}{r}4 \\
2 \\
11 \\
11 \\
4 \\
9 \\
5 \\
5 \\
9 \\
11 \\
14 \\
14 \\
11 \\
4 \\
9 \\
10 \\
10 \\
12 \\
9 \\
10\end{array}$ & $\begin{array}{r}2 \\
1 \\
5 \\
11 \\
2 \\
7 \\
3 \\
3 \\
7 \\
9 \\
10 \\
8 \\
8 \\
3 \\
9 \\
8 \\
7 \\
11 \\
1 \\
5\end{array}$ & $\begin{array}{l}1 \\
0 \\
2 \\
8 \\
0 \\
4 \\
1 \\
1 \\
6 \\
9 \\
7 \\
5 \\
5 \\
0 \\
3 \\
5 \\
4 \\
7 \\
1 \\
5\end{array}$ \\
\hline Total & 441 & 3004 & 222 & 221 & 218 & 432 & 2550 & 174 & 120 & 74 \\
\hline Mean & $22 \cdot 05$ & $158 \cdot 1$ & $11 \cdot 1$ & $11 \cdot 0$ & $10 \cdot 9$ & $21 \cdot 6$ & $134 \cdot 2$ & $8 \cdot 7$ & 6 & $3 \cdot 7$ \\
\hline
\end{tabular}

* Weight on 21 st day of pregnancy expressed as a percentage of weight at the time of mating.

$+\mathrm{ND}=$ Not determined. 
normal course of weight increase during pregnancy. This effect is attributed to the inoculation, or the accompanying anaesthesia, or both.

\section{Experimental and control rats in their second (manipulated) pregnancies}

Examination of the data reveals the effects of mycoplasma infection. Table III clearly shows that the percentage of offspring alive at birth was significantly $(\mathrm{P}<0.001)$ higher in the control group than in the experimental group. The same was true of the percentage of offspring alive 10 days after birth. In addition, the mean litter size of the experimental group was less than that of the control group, and less than that of either group in the first (normal) pregnancy.

TABLE III

Data relevant to the effects of mycoplasma infection on reproduction, derived from control and experimental rats in their first (normal) and second (manipulated) pregnancies

\begin{tabular}{ccl|cccc} 
Pregnancy & $\begin{array}{c}\text { Number } \\
\text { of } \\
\text { rats }\end{array}$ & $\begin{array}{c}\text { Treatment } \\
\text { during } \\
\text { pregnancy }\end{array}$ & $\begin{array}{c}\text { Mean } \\
\text { duration } \\
\text { of } \\
\text { pregnancy } \\
\text { (days) }\end{array}$ & $\begin{array}{c}\text { Mean } \\
\text { total } \\
\text { number } \\
\text { of } \\
\text { offspring }\end{array}$ & $\begin{array}{c}\text { Mean } \\
\text { percentage } \\
\text { of offspring } \\
\text { alive at } \\
\text { birth }\end{array}$ & $\begin{array}{c}\text { Mean } \\
\text { of offspring } \\
\text { alive 10 days } \\
\text { after birth }\end{array}$ \\
\hline 1st & 11 & None & 22 & 9.5 & 100 & 98.1 \\
2nd & 20 & None & 22.05 & $11 \cdot 1$ & 99.5 & 98.2 \\
& 11 & $\begin{array}{c}\text { Broth } \\
\text { injection }\end{array}$ & 21.4 & 10.5 & 98.2 & 93.9 \\
\hline
\end{tabular}

This table is based on information given in tables I and II.

Microbiological and clinical examination of rats

No arthritis was seen in any animal. Of the animals killed for examination, all from the experimental group but none from the control group had foetuses and placentae that were infected with mycoplasmas. These findings confirm our previous report (Klein et al., 1978).

\section{Discussion}

Our results clearly demonstrate that mycoplasma infection has an adverse effect on pregnancy in rats. This effect was reflected in a significant decrease in size of litter, and reduced viability of offspring at birth and, still more, at 10 days after birth. The smaller weight increase observed in mycoplasma-infected pregnant rats than in control pregnant rats (see tables I and II) was compatible with the reduced number of foetuses. The decrease was attributable to foetal resorption.

Our results are in agreement with those of Taylor-Robinson et al. (1975) in showing that mycoplasma infection of pregnant rodents can affect foetal survival; they also show that survival of the newborn offspring can be affected. 
On an earlier occasion we showed that $M$. arthritidis induced extensive nonspecific lymphocyte transformation in rats (Naot, Tully and Ginsburg, 1977); this observation, together with the well-documented isolation of mycoplasma from foetal organs (Taylor-Robinson et al., 1975; Klein et al., 1978), raises the question of whether pathogenicity is associated with mitogenicity.

\section{SUMMARY}

The controversy regarding the possible role of genital mycoplasma infection in human reproductive failure gave rise to a study in which pregnant rats, previously shown to be of normal fertility, were inoculated 7-11 days after conception with either Mycoplasma arthritidis or an equal volume of sterile broth medium. Repeated observations during the course of pregnancy revealed several pathogenic effects.

A statistically significant decrease was observed in the mean litter size of infected mothers. Furthermore, the offspring showed low viability at birth and, still more, at 10 days after birth. Our data are compatible with the hypothesis that genital mycoplasma infection plays a role in reproductive failure.

The authors are indebted to Mrs Rama Siman-Tov for her excellent technical assistance.

\section{REFERENCES}

Beck, D., Ginsburg, H. AND NAOT, Y. 1977. The modulating effect of human chorionic gonadotrophin on lymphocyte blastogenesis. Am.J. Obstet. Gynec., 129, 14.

Braun, P., Lee, Y. H., Klein, J. O., Marcy, S. M., Klein, T. A., Charles, D., Levy, P. and KAss, E. H. 1971. Birth weight and genital mycoplasmas in pregnancy. New Engl. J. Med., 284, 167.

Caspi, E., Solomon, F. And Sompolinsky, D. 1972. Early abortion and mycoplasma infection. Israel J. med. Sci., 8, 122.

Cole, B. C., Golightly-Rowland, L. AND Ward, J. R. 1976. Arthritis of mice induced by Mycoplasma arthritidis. Humoral antibody and lymphocyte responses of CBA mice. Ann. rheum. Dis., 35, 14.

De Louvois, J., Blades, M., Harrison, R. F., Hurley, R. and Stanley, V. C. 1974. Frequency of mycoplasma in fertile and infertile couples. Lancet, 1, 1073.

Ganaway, J. R., Allen, A. M., Moore, T. D. ANd Bohner, H. J. 1973. Natural infection of germfree rats with Mycoplasma pulmonis. J. infect. Dis., 127, 529.

Harwick, H. J., IupPa, J. B., Purcell, R. H. AND FeKety, F. R. 1967. Mycoplasma hominis septicemia associated with abortion. Am. J. Obstet. Gynec., 99, 725.

HAYfLICK, L. 1965. Tissue cultures and mycoplasma. Tex. Rep. Biol. Med., Suppl. 1, 23, 285.

JONES, D. M. 1967a. Mycoplasma hominis in pregnancy. J. clin. Path., 20, 633.

JoNES, D. M. 1967b. Mycoplasma hominis in abortion. Br. med. J., 1, 338.

Klein, J. O., Buckland, D. ANd Finland, M. 1969. Colonization of newborn infants by mycoplasmas. New Engl. J. Med., 280, 1025.

Klein, A., Sharf, M., Zilberman, A., Ginsburg, H. ANd Naot, Y. 1978. Mycoplasma infection in gravid rats: fetal infection and impaired weight increase during gestation. Harefuah, 94, 63.

Kundsin, R. B. AND Driscoll, S. G. 1970. Mycoplasma and human reproductive failure. Surgery Gynec. Obstet., $131,89$.

LEMCKe, R. M. 1964. The serological differentiation of mycoplasma strains (PPLO) from various sources. J. Hyg., Camb., 62, 199. 
NaOt, Y., Tully, J. G. AND Ginsburg, H. 1977. Lymphocyte activation by various mycoplasma strains and species. Infect. Immun., 18, 310.

Taylor-Robinson, D., Rassner, C., Furr, P. M., Humber, D. P. and Barnes, R. D. 1975. Fetal wastage as a consequence of Mycoplasma pulmonis infection in mice. J. Reprod. Fert., 42, 483.

Tully, J. G. 1965. Biochemical, morphological and serological characterization of mycoplasma of murine origin. J. infect. Dis., 115, 171.

Tully, J. G. 1969. Murine mycoplasmas. In The mycoplasmatales and the L-phase of bacteria, edited by L. Hayflick, New York, p. 571.

WARD, J. R. AND JONES, R. S. 1962. The pathogenesis of mycoplasma (PPLO) arthritis in rats. Arthritis Rheum., 5, 163. 